\title{
Payment method as a predictor of daily distress experienced by physicians
}

\author{
Juan Nicolás Peña-Sánchez ${ }^{1}$, Rein Lepnurm¹, David Keegan², Roy T. Dobson ${ }^{3}$, Silvia \\ Bermedo-Carrasco ${ }^{1}$
}

1. School of Public Health, University of Saskatchewan, Canada. 2. Department of Psychiatry, College of Medicine, University of Saskatchewan, Canada. 3. College of Pharmacy and Nutrition, University of Saskatchewan, Canada.

Correspondence: Juan Nicolás Peña-Sánchez. Address: School of Public Health, University of Saskatchewan, 104 Clinc Place, Saskatoon, SK., S7N 5E5, Canada. E-mail: juan.nicolas.ps@usask.ca

Received: December 11, 2013

Accepted: March 12, 2014

Online Published: March 31, 2014

DOI : 10.5430/jha.v3n5p1

URL: http://dx.doi.org/10.5430/jha.v3n5p1

\begin{abstract}
Background: Physicians face intrinsic tensions when practicing medicine; therefore, extrinsic factors that could affect distress, such as payment methods, need to be assessed. The study objectives were to: compare levels of distress by payment method, identify factors predicting distress in a two-level regression model, and explore interactions between predictors of distress and payment method.

Methods: A cross-sectional study was conducted among physicians in the Saskatoon Health Region, Saskatchewan. Physicians completed a pre-tested questionnaire about their distress. Analysis of variance was used to compare distress levels of physicians paid by fee-for-service (FFS), alternative payment plans (APPs), and blended methods. A mixed linear regression model was built to predict distress with geographical area of practice as the random component. Demographics, workload, complexity of patients, payment method, career satisfaction, and practice profile were the independent variables. The interactions between payment method and predictors of daily distress were evaluated.

Results: A total of 382 physicians participated (response rate $=48.1 \%$ ). Response bias was tested and found to be negligible. In the multivariable analysis, payment method was a predictor of distress which interacted with the proportion of complex cases. Lower levels of distress were found among physicians who had more than $75 \%$ of patients with complex conditions and were paid by APPs, compared to those paid by FFS and blended methods. Career satisfaction was found to be an important predictor. Nine percent of the outcome variation was explained by geographic area of practice.

Conclusions: Payment method is a predictor of distress when adjusting by confounders, interacting with proportion of complex cases. APPs may promote provision of care for patients with complex conditions. Career satisfaction can be considered a protective indicator of distress. Practice environment influences distress experienced by physicians.
\end{abstract}

\section{Key words}

Daily distress, Physicians, Predictors, Payment methods, Fee-for-service, Alternative payment plans

\section{I ntroduction}

Health care professionals experience greater risk for burnout than other human service occupations ${ }^{[1,2]}$, and critical care environments are the most stressful ${ }^{[3,4]}$. Other professionals such as teachers, lawyers, social workers, psychologists are 
also at risk of emotional exhaustion because relationships of trust are formed between providers of service and clients ${ }^{[2]}$. The distress faced by physicians and nurses is of ultimate legal responsibility over outcomes and pressures from high workloads ${ }^{[5-7]}$. Medical doctors are at a higher risk for burnout in comparison to individuals in other non-medical professions ${ }^{[1]}$, and high stress among physicians affects well-being of these health professionals and quality of care provided to patients ${ }^{[8-13]}$.

Physicians face intrinsic and unalterable tensions when practicing medicine due to working within an emotionally-charged environment, dealing with suffering and fear ${ }^{[8,14]}$. The practice of medicine has repetitive and unavoidable daily distresses which are particularly evident in certain areas of care (e.g., intensive care units, emergency, and operating rooms) ${ }^{[1,9]}$. Medical errors tend to occur when practitioners face intense physical and mental exhaustion ${ }^{[15]}$, and physicians are stressed when the quality of care is not as good as it could be ${ }^{[16]}$. Deterioration of physician-patient relationship ${ }^{[13,17]}$, increases in the amount of tests ordered ${ }^{[8,13]}$, and increases in the likelihood of medical errors ${ }^{[13,17]}$ have been observed among highly stressed physicians.

In Europe and North America, about a quarter of physicians suffer from high levels of stress ${ }^{[10,11]}$. In Canada, about $40 \%$ of physicians feel stressed at least once a week, emergency physicians and surgeons are specialists experiencing the highest levels of distress ${ }^{[9]}$, and burnout and stress are commonly reported among family practitioners ${ }^{[9,12]}$. Declines in clinical autonomy, increases in workloads, organizational changes, practice restrictions, and career dissatisfaction have been identified as added sources of stress in medical practice ${ }^{[8,13,17,18]}$. Governmental budget constraints to control rising system costs are further sources of stress since physicians experiencing changes to their workload have to find ways to access services and resources for the care of their patients ${ }^{[19]}$. In privately funded health care systems, interventions by health insurance companies restrict the autonomy and income of physicians, potentially affecting the quality of care ${ }^{[8]}$. These factors increase the inherent daily distress of medical practice, perpetuating a vicious circle of strain and stress. Furthermore, among different organizational and system changes, shifts in the way that physicians are paid have been suggested as sources of strain that might increase distress that physicians experience in their daily practice ${ }^{[10]}$.

Since the introduction of Medicare in Canada, physicians have been traditionally paid by provincial/territorial governments through fee-for-service (FFS) schemes ${ }^{[20]}$. A considerable proportion of the increase in the health care expenditures has been attributed to FFS payment for physicians ${ }^{[21]}$. Alternative payment plans (APPs) have been introduced, including salaries, capitation, sessional and blended schemes with FFS across Canada. During the last decade, APPs have doubled their share among all payment methods for physicians ${ }^{[22,23]}$; notwithstanding, there is disagreement about the impact of APPs on the distress levels of physicians. Among Canadian family practitioners, no association was reported between stress and type of remuneration ${ }^{[12]}$. In the United Kingdom (UK), salaried physicians experienced less stress in carrying out management tasks than non-salaried practitioners ${ }^{[24]}$; however, higher stress levels were identified in the UK after the implementation of a specific contract which aimed to promote multidisciplinary teamwork ${ }^{[25]}$.

The impact of payment schemes on the levels of stress among physicians requires considering confounding variables, such as practice features and allocation of time to academic and administrative duties. Consequently, the objectives of this study were to: 1) compare distress levels of physicians among FFS, APPs, and blended schemes, in an unconditional analysis; 2) identify payment method and other factors predicting daily distress of physicians in a multi-level regression model, considering confounders which could affect associations; and 3) explore interactions between predictors of daily distress and payment method for practicing medicine.

\section{Methods}

\subsection{Study design}

A cross-sectional study was conducted in the Saskatoon Health Region (SHR), Saskatchewan, Canada, in 2011, by the MERCURi Research Group at the University of Saskatchewan. The SHR is the largest health authority of the province, 
including rural and urban areas, providing health care to about one third of the population of Saskatchewan, from primary services to specialized care, in an academic medical complex consisting of multiple health care organizations ${ }^{[26]}$.

In this study, all physicians practicing in the region received a comprehensive questionnaire asking about daily levels of distress, practice settings, working hours, workload, payment method, and demographics. Physicians eligible to participate in the study were medical doctors on the list of practitioners in the SHR and who were practicing at the time of the study; those physicians who were on a leave of absence or in a residency program were not eligible to participate in the study. Applying the Dillman Method ${ }^{[27]}$, eligible physicians received a cover letter, a questionnaire, and a prepaid return envelope by post inviting them to participate in the study. An on-line option to participate was also offered by e-mail. Three reminders followed the initial invitation. In addition, a one-page questionnaire was attached to the last reminder in order to test non-response bias. The Behavioral Research Ethics Board of the University of Saskatchewan and the SHR provided ethical and operational approvals, respectively.

Table 1. Questionnaire to measure daily distress of physicians used in the present study

\begin{tabular}{|c|c|c|c|c|c|c|c|}
\hline How frequently do you: & Never & $\begin{array}{l}\text { A few times } \\
\text { a year }\end{array}$ & $\begin{array}{l}\text { Once a } \\
\text { month }\end{array}$ & $\begin{array}{l}2 \text { - } 3 \text { times } \\
\text { a month }\end{array}$ & $\begin{array}{l}\text { Once a } \\
\text { week }\end{array}$ & $\begin{array}{l}2-3 \text { times } \\
\text { a week }\end{array}$ & $\begin{array}{l}\text { Every } \\
\text { day }\end{array}$ \\
\hline $\begin{array}{l}\text { Have workdays which are so busy that you } \\
\text { are physically exhausted at the end of the } \\
\text { day? }\end{array}$ & [ ] & [ ] & [ ] & [ ] & [ ] & [ ] & [ ] \\
\hline $\begin{array}{l}\text { Have such demanding workdays that you are } \\
\text { emotionally drained at the end of the day? }\end{array}$ & [ ] & [ ] & [ ] & [ ] & [ ] & [ ] & [ ] \\
\hline $\begin{array}{l}\text { Suffer from fatigue due to working late nights } \\
\text { and/or nights? }\end{array}$ & [ ] & [ ] & [ ] & [ ] & [ ] & [ ] & [ ] \\
\hline $\begin{array}{l}\text { Express impatience when people do not } \\
\text { respond to requests as quickly as they should } \\
\text { have? }\end{array}$ & [ ] & [ ] & [ ] & [ ] & [ ] & [ ] & [ ] \\
\hline $\begin{array}{l}\text { Express anger when people at work make } \\
\text { mistakes? }\end{array}$ & [ ] & [ ] & [ ] & [ ] & [ ] & [ ] & [ ] \\
\hline $\begin{array}{l}\text { Have workdays when you can devote enough } \\
\text { time to all of your patients? }\end{array}$ & [ ] & [ ] & [ ] & [ ] & [ ] & [ ] & [ ] \\
\hline $\begin{array}{l}\text { Feel frustrated accessing facilities/services } \\
\text { for patients? }\end{array}$ & [ ] & [ ] & [ ] & [ ] & [ ] & [ ] & [ ] \\
\hline $\begin{array}{l}\text { Feel depressed because of the death or serious } \\
\text { illness of a patient? }\end{array}$ & [ ] & [ ] & [ ] & [ ] & [ ] & [ ] & [ ] \\
\hline $\begin{array}{l}\text { Feel that your work has desensitized your } \\
\text { feelings/ emotions? }\end{array}$ & [ ] & [ ] & [ ] & [ ] & [ ] & [ ] & [ ] \\
\hline $\begin{array}{l}\text { Experience frustration dealing with } \\
\text { demanding patients? }\end{array}$ & [ ] & [ ] & [ ] & [ ] & [ ] & [ ] & [ ] \\
\hline $\begin{array}{l}\text { End up doing tasks which you think are } \\
\text { outside of your responsibilities? }\end{array}$ & [ ] & [ ] & [ ] & [ ] & [ ] & [ ] & [ ] \\
\hline $\begin{array}{l}\text { Cancel a personal or social activity in order to } \\
\text { meet work commitments? }\end{array}$ & [ ] & [ ] & [ ] & [ ] & [ ] & [ ] & [ ] \\
\hline $\begin{array}{l}\text { Experience conflict between responsibilities } \\
\text { at work and at home? }\end{array}$ & [ ] & [ ] & [ ] & [ ] & [ ] & [ ] & [ ] \\
\hline $\begin{array}{l}\text { Feel that you can concentrate on the tasks that } \\
\text { should be done? }\end{array}$ & [ ] & [ ] & [ ] & [ ] & [ ] & [ ] & [ ] \\
\hline $\begin{array}{l}\text { Feel that you are in control of your } \\
\text { day-to-day working activities? }\end{array}$ & [ ] & [ ] & [ ] & [ ] & [ ] & [ ] & [ ] \\
\hline $\begin{array}{l}\text { Feel confident that you have been able to do } \\
\text { your work at a high standard of care? }\end{array}$ & [ ] & [ ] & [ ] & [ ] & [ ] & [ ] & [ ] \\
\hline How would you rate your level of stress? & \multicolumn{2}{|c|}{ [Very Low] } & ow] & [Moderate] & \multicolumn{2}{|c|}{$[\mathrm{High}]$} & high] \\
\hline
\end{tabular}




\subsection{Measures}

The Daily Distress measure developed by Lepnurm, Lockhart, and Keegan ${ }^{[9]}$ was used. This measure evaluated the concepts of fatigue and reaction, identifying those practitioners who need more time off than a weekend, those with feelings of frustration and desensitization, and those who are at risk of burnout ${ }^{[9]}$. The distress measure had one overall question of distress and 16 items all scored on 7 point scales from never to daily (see Table 1). Levels of daily distress experienced by physicians were standardized by summing the items and dividing by 16 , yielding standardized scores ranging from a minimum 1.00 to a maximum of 7.00 .

As independent variables, physicians were asked about the number of patients seen per week, proportion of patients seen with complex medical/social conditions, number of hours worked per week, and time spent on patient care, academic, and administrative activities. Physicians were asked about their payment methods for medical practice, capturing proportions of payments received by FFS and APPs. Then, payment methods were classified in three groups: paid only by FFS or APPs, and paid by blended schemes of FFS and APPs. In addition, levels of career satisfaction of physicians were measured using a 16-item questionnaire previously tested among Canadian physicians ${ }^{[28]}$.

\subsection{Statistical analyses}

The reliabilities of the measures were confirmed using Cronbach's alpha coefficients of internal consistency ${ }^{[29]}$. A Pearson correlation coefficient was computed between reported overall levels of stress and standardized distress levels. One-way analysis of variance (ANOVA) was used to compare standardized scores of daily distress according to payment method as an unconditional evaluation. Also, ANOVAs and T-Tests were used to identify the main factors affecting daily distress of physicians.

\section{Multivariable analysis}

Since several variables might act as confounders in the relationship between payment method and daily distress levels, a multivariable analysis was required to identify predictors of distress and the role of payment method as a predictor in this model. Also, given that distress of physicians could be clustered by geographical area of practice within the SHR (distress of physicians practicing in rural areas might be more similar than those practicing in urban areas, or distress of those in deprived areas of the city could be more alike, as well as the distress experienced by those working within the same hospitals, clinic, and medical centers), a multiple-level model was built to account for individual (fixed portion) and unmeasured environmental factors (random component). Thus, the first three postal code characters - Forward Sortation Area (FSA) - of physicians' mailing addresses were used in the random portion of the model. The FSA was considered as a geographical proxy to account for the influence of environment on daily distress. Age, gender, specialty group, career satisfaction, regular working hours per week, number of weekends on call, number of patients per week during regular hours and on call, proportion of patients with complex conditions, time devoted to academic and administrative activities, practice setting, and payment method were considered as independent variables in the fixed portion of the model.

First, a null model was built to evaluate clustering of the outcome using the intra-class correlation coefficient $($ ICC) $=$ $\sigma_{\mu}^{2} /\left(\sigma_{\mu}^{2}+\sigma_{\varepsilon}^{2}\right)^{[30]}$, where $\sigma_{\mu}^{2}$ is the variance at the FSA level and $\sigma_{\varepsilon}^{2}$ is the variance at the individual level. Unconditional analyses were performed for each independent variable. The assumption of linearity between the outcome and the independent variables was checked with a quadratic term for the continuous independent variables to decide whether to include them as continuous or categorical variables. Then, the backward method was used in the model building process. Excluded variables were tested as confounders. Interactions between payment method and predictors of daily distress were also evaluated. Using the final model, mean predicted values were computed and depicted for interacting variables. Residuals for the cluster and individual levels were evaluated. Analyses were performed in STATA 12 and the model building was carried out using the xtmixed procedure, at a 5\% level of significance. 


\section{Results}

From the 794 eligible physicians, 382 doctors completed the questionnaire, corresponding to a $48.1 \%$ response rate. Geographically, participants had their offices distributed among 12 FSA within the SHR (on average, 31.8 physicians per FSA with $91.7 \%$ of units replicated). As presented in Table 2, the mean age in the sample was $49.0(S D=11.40)$ years, 142 were females and 240 were males. On regular hours, physicians reported working $54.9(S D=16.55)$ hours/week on average; only $15.4 \%$ of the participants reported that they work 40 or less hours per week and $20 \%$ of them stated that they work more than 3 weekends per month. Of total regular working hours, on average, $27.2 \%$ of the time was dedicated to academic activities and $8.7 \%$ to administrative duties. The mean number of patients seen per week was $84.9(S D=76.21)$; the average proportion of patients with complex socio-medical conditions was $47.3 \%(S D=25.79)$. Regarding payment method, 173 physicians were paid by FFS, 94 by APPs, and 115 by blended schemes. Table 2 also presents demographic, workload, practice organizational, and well-being factors by payment methods. Non-response bias was checked by comparing participants and non-participants according to age group, specialty group, gender, distress, and satisfaction levels; and found to be negligible.

Table 2. Descriptive statistics of respondents in the sample and by payment method: mean $(S D)$ and $\mathrm{n}(\%)$

\begin{tabular}{|c|c|c|c|c|}
\hline \multirow{2}{*}{$\mathbf{N}=\mathbf{3 8 2}$} & \multirow{2}{*}{$\begin{array}{l}\text { Total } \\
\text { Group }\end{array}$} & \multicolumn{3}{|c|}{ Payment method } \\
\hline & & FFS $(45.3 \%)$ & Blended $(30.1 \%)$ & APPs $(24.6 \%)$ \\
\hline \multicolumn{5}{|l|}{ Demographic factors } \\
\hline Age (years-old) & $49.04(11.40)$ & $50.60(11.78)$ & $48.03(10.84)$ & $47.41(11.09)$ \\
\hline \multicolumn{5}{|l|}{ Gender } \\
\hline Female & $142(37.2 \%)$ & $59(41.5 \%)$ & $44(31 \%)$ & $39(27.5 \%)$ \\
\hline Male & $240(62.8 \%)$ & $114(47.5 \%)$ & $71(29.6 \%)$ & $55(22.9 \%)$ \\
\hline \multicolumn{5}{|l|}{ Specialty group } \\
\hline Family/general practitioners & $136(35.6 \%)$ & $101(74.3 \%)$ & $15(11 \%)$ & $20(14.7 \%)$ \\
\hline Medical-surgical specialists & $233(61 \%)$ & $72(30.9 \%)$ & $100(42.9 \%)$ & $61(26.2 \%)$ \\
\hline Pathologists & $13(3.4 \%)$ & - & - & $13(100 \%)$ \\
\hline \multicolumn{5}{|l|}{ Workload factors } \\
\hline Regular working hours(total number of hours x week) & $54.90(16.55)$ & $55.49(17.51)$ & $57.02(16.86)$ & $51.24(13.67)$ \\
\hline Patients seen on regular hours(number patients $\mathrm{x}$ week) & $84.88(76.21)$ & $109.31(80.44)$ & $61.65(69.02)$ & $68.33(62.72)$ \\
\hline \multicolumn{5}{|l|}{ Number of weekends on call } \\
\hline None & $75(19.6 \%)$ & $35(46.7 \%)$ & $11(14.7 \%)$ & $29(38.7 \%)$ \\
\hline One & $118(30.9 \%)$ & $54(45.8 \%)$ & $35(29.7 \%)$ & $29(24.6 \%)$ \\
\hline Two & $111(29.1 \%)$ & $44(39.6 \%)$ & $42(37.8 \%)$ & $25(22.5 \%)$ \\
\hline Three or more & $77(20.2 \%)$ & $39(50.6 \%)$ & $27(35.1 \%)$ & $11(14.3 \%)$ \\
\hline $\begin{array}{l}\text { Patients seen on call } \\
\text { (number patients } \mathrm{x} \text { week) }\end{array}$ & $12.35(24.15)$ & $13.09(23.51)$ & $17.52(31)$ & $4.66(9.76)$ \\
\hline $\begin{array}{l}\text { Patients with complex socio-medical conditions } \\
\text { (proportion of total patients) }\end{array}$ & $47.33(25.79)$ & $40.46(24.33)$ & $53.24(25.07)$ & $52.77(26.42)$ \\
\hline \multicolumn{5}{|l|}{ Practice organizational factors } \\
\hline \multicolumn{5}{|l|}{ Practice setting } \\
\hline Solo practice & $70(18.3 \%)$ & $33(47.1 \%)$ & $17(24.3 \%)$ & $20(28.6 \%)$ \\
\hline Group practice & $312(81.7 \%)$ & $140(44.9 \%)$ & $98(31.4 \%)$ & $74(23.7 \%)$ \\
\hline $\begin{array}{l}\text { Time dedicated to academic duties (proportion of total } \\
\text { working hours) }\end{array}$ & $27.17(21.94)$ & $17.94(17.85)$ & $36.16(21.63)$ & $33.17(22.67)$ \\
\hline $\begin{array}{l}\text { Time dedicated to administrative duties (proportion of } \\
\text { total working hours) }\end{array}$ & $(12.10)$ & $6.14(8.04)$ & $9.14(10.97)$ & $12.83(17.42)$ \\
\hline
\end{tabular}


Table 2. (continued.)

\begin{tabular}{|c|c|c|c|c|}
\hline \multirow{2}{*}{$\mathbf{N}=\mathbf{3 8 2}$} & \multirow{2}{*}{$\begin{array}{l}\text { Total } \\
\text { Group }\end{array}$} & \multicolumn{3}{|c|}{ Payment method } \\
\hline & & FFS $(45.3 \%)$ & Blended $(30.1 \%)$ & APPs (24.6\%) \\
\hline \multicolumn{5}{|l|}{ Well-being factors } \\
\hline Career satisfaction level ${ }^{*}$ & $4.22(0.61)$ & $4.19(0.63)$ & $4.25(0.63)$ & $4.25(0.54)$ \\
\hline Daily distress levels ${ }^{\dagger}$ & $3.31(0.89)$ & $3.34(0.95)$ & $3.22(0.86)$ & $3.36(0.81)$ \\
\hline \multicolumn{5}{|l|}{ Overall perceived stress } \\
\hline Very low & $13(3.4 \%)$ & $7(58.8 \%)$ & $3(23.1 \%)$ & $3(23.1 \%)$ \\
\hline Low & $68(17.8 \%)$ & $35(51.5 \%)$ & $22(32.4 \%)$ & $11(16.2 \%)$ \\
\hline Moderate & $192(50.4 \%)$ & $86(44.8 \%)$ & $57(29.7 \%)$ & $49(25.5 \%)$ \\
\hline High & $94(24.7 \%)$ & $35(37.2 \%)$ & $30(31.9 \%)$ & $29(30.9 \%)$ \\
\hline Very high & $14(3.7 \%)$ & $10(71.4 \%)$ & $3(21.4 \%)$ & $1(7.1 \%)$ \\
\hline
\end{tabular}

${ }^{*}$ Cronbach's $\alpha$ of the career satisfaction measure $=0.84 ;{ }^{\dagger}$ Cronbach's $\alpha$ of the daily distress measure $=0.87$

According to the overall levels of stress reported by physicians, $21.2 \%$ experienced very low or low stress, $50.4 \%$ moderate, and $28.4 \%$ high or very high (see Table 2). In the standardized distress score from 1.00 to 7.00 , the mean level of daily distress experienced by physicians was $3.31(S D=0.89)$, and the median was 3.31 . The reliability for the daily distress 16-item questionnaire was very good $(\alpha=0.87$ ), and was similar across specialty groups (family and general practitioners $[\alpha=0.89)$, medical-surgical specialists $[\alpha=0.86$ ), and pathologists $[\alpha=0.90)$ ). The correlation between standardized distress score with the overall perceived stress was $r=0.62(P<.001)$. The standardized score of daily distress experienced by physicians was used as the dependent continuous variable for the subsequent unconditional and multivariable analyses.

\subsection{Unconditional analyses}

By payment method, ANOVA did not identify significant differences in levels of daily distress, $\mathrm{F}(2,379)=0.78(P=.46)$. Unconditional analyses showed that the main factors affecting daily distress were age group, $\mathrm{F}(3,376)=10.41(P<.001)$, hours worked per week, $\mathrm{F}(2,379)=10.58(P<.001)$, number of patients seen on regular hours, $\mathrm{F}(2,379)=15.78(P<$ $.001)$, number of weekends on call, $\mathrm{F}(3,377)=6.14(P<.001)$, and practice setting, $\mathrm{t}(380)=-2.81(P=.005)$. As presented in Table 3, higher levels of distress were identified among younger physicians in comparison to older physicians $(P<.001)$, those working more than 61 hours/week versus practitioners working less than 48 hours/week $(P<.001)$, physicians who see more 100 patients/week versus those who see less than 40 patients/week $(P<.001)$, practitioners working three or more weekends or holidays per month in comparison to those that do not $(P=.004)$, and among physicians working in a group versus those in a solo practice $(P=.005)$.

The null model identified that $8 \%$ of the variation in the outcome was explained by clustering of physicians (ICC $=0.08$, $95 \% \mathrm{CI} 0.02$ to 0.28 ). Then, the majority of the predictors were significant in the unconditional analyses; only time devoted to academic duties, specialty group, and payment method were not significant ( $P$-values $>.05)$. Payment method was considered in the multivariable analysis, since we hypothesized that it is a predictor of distress when controlling by confounders. Only career satisfaction and number of patients seen on call met the linearity assumption, being used in their continuous form. Other continuous independent variables were classified into categories based on their distribution: working hours/week, number of patients seen on regular hours per week, time devoted to academic and administrative duties, and percentage of patients with complex socio-medical conditions were divided by tertiles.

\subsection{Multivariable analysis}

Using the backward method, an initial model was defined. This model included as significant predictors of distress: payment method $(P=.04)$, age group $(P<.001)$, number of patients/week on regular hours $(P<.001)$, number of weekends on call $(P=.04)$, proportion of patients with complex conditions $(P=.01)$, and career satisfaction $(P<.001)$; Akaike Information Criterion $(\mathrm{AIC})=804.33$. Then, removed variables of the model were tested as confounders. Regular working hours/week were found to confound the coefficients of payment method and proportion of complex patients; time devoted to academic duties confounded the coefficients of payment method; and time dedicated to administrative tasks 
confounded the coefficients of age group and payment method. Along with gender ${ }^{[31,32]}$, regular working hours/week, time devoted to academic duties, and time dedicated to administrative tasks were added to obtain an adjusted model with ten predictors $(\mathrm{AIC}=806.97)$. Afterwards, interactions between predictors of distress and payment methods were tested. Only one significant interaction was identified: payment method interacted with the proportion of patients with complex socio-medical conditions, $\chi^{2}=12.23, \mathrm{df}=2 ; P=.02$.

Table 3. Daily distress of physicians according to demographics, workload, and practice organizational factors $(\mathrm{N}=382)$

\begin{tabular}{|c|c|c|}
\hline Variable & Categories & Daily distress Mean (SD) \\
\hline \multicolumn{3}{|l|}{ Demographic factors } \\
\hline \multirow{4}{*}{ Age group } & $<41$ year-old & $3.47(0.81)^{*}$ \\
\hline & 41 - 49 year-old & $3.57(0.77)$ \\
\hline & 50 - 59 year-old & $3.24(0.90)$ \\
\hline & $>59$ year-old & $2.87(0.96)^{\ddagger}$ \\
\hline \multirow{2}{*}{ Gender } & Female & $3.43(0.84)$ \\
\hline & Male & $3.24(0.92)$ \\
\hline \multirow{3}{*}{ Specialty group } & Family/general practitioners & $3.45(0.96)$ \\
\hline & Medical-surgical specialists & $3.23(0.84)$ \\
\hline & Pathologists & $3.34(0.99)$ \\
\hline \multicolumn{3}{|l|}{ Workload factors } \\
\hline \multirow{3}{*}{ Regular working hours per week } & $<48$ & $3.06(0.97)^{*}$ \\
\hline & $48-61$ & $3.30(0.80)$ \\
\hline & $>61$ & $3.56(0.83)^{\ddagger}$ \\
\hline \multirow{3}{*}{ Number of patients seen on regular hours $\mathrm{x}$ week } & $<40$ & $2.93(0.85)^{\ddagger}$ \\
\hline & $40-100$ & $3.43(0.85)^{\ddagger}$ \\
\hline & $>100$ & $3.50(0.88)^{\ddagger}$ \\
\hline \multirow{4}{*}{ Number of weekend days on call } & None & $3.00(0.99)^{\dagger}$ \\
\hline & One & $3.22(0.88)$ \\
\hline & Two & $3.46(0.82)^{\dagger}$ \\
\hline & Three or more & $3.53(0.82)^{\dagger}$ \\
\hline \multirow{3}{*}{ Number of patients seen on call $\mathrm{x}$ week } & None & $3.20(1.01)$ \\
\hline & One to 10 & $3.29(0.83)$ \\
\hline & 11 or more & $3.48(0.84)$ \\
\hline \multirow{3}{*}{ Patients with complex socio-medical conditions } & $<25 \%$ & $3.15(0.89)$ \\
\hline & $25 \%-75 \%$ & $3.34(0.92)$ \\
\hline & $>75 \%$ & $3.40(0.80)$ \\
\hline \multicolumn{3}{|l|}{ Practice organizational factors } \\
\hline \multirow{3}{*}{ Payment method } & FFS & $3.34(0.95)$ \\
\hline & Blended & $3.22(0.86)$ \\
\hline & APPs & $3.36(0.81)$ \\
\hline \multirow{2}{*}{ Practice setting } & Solo practice & $3.04(0.99)^{\dagger}$ \\
\hline & Group practice & $3.37(0.86)^{\dagger}$ \\
\hline \multirow{3}{*}{ Time dedicated to academic duties } & $<10 \%$ & $3.47(0.96)$ \\
\hline & $10 \%-30 \%$ & $3.26(0.83)$ \\
\hline & $>30 \%$ & $3.22(0.88)$ \\
\hline \multirow{3}{*}{ Time dedicated to administrative duties } & $<5 \%$ & $3.23(0.98)$ \\
\hline & $5 \%-10 \%$ & $3.43(0.79)$ \\
\hline & $>10 \%$ & $3.32(0.81)$ \\
\hline
\end{tabular}

${ }^{\dagger} p<.01 ;{ }^{\ddagger} p<.001$ 
Table 4. Non-interacting predictors of daily distress obtained in the multilevel linear regression model ${ }^{*}, \dagger, \ddagger$

\begin{tabular}{|c|c|c|c|c|}
\hline Covariant & categories & $\bar{\beta}$ & $95 \% \mathrm{CI}$ & $P$-value \\
\hline \multirow{4}{*}{ Age group (year-old) } & $<41$ & ref. & & \\
\hline & $41-49$ & 0.04 & $(-0.15$ to 0.24$)$ & .70 \\
\hline & $50-59$ & -0.21 & $(-0.39$ to -0.03$)$ & .02 \\
\hline & $>59$ & -0.51 & $(-0.72$ to -0.30$)$ & $<.001$ \\
\hline \multirow{2}{*}{ Gender } & Female & ref. & & \\
\hline & Male & -0.07 & $(-0.22$ to 0.08$)$ & .38 \\
\hline \multirow{3}{*}{ Regular working hours $\mathrm{x}$ week } & $<48$ & ref. & & \\
\hline & $48-61$ & -0.04 & $(-0.22$ to 0.13$)$ & .63 \\
\hline & $>61$ & 0.14 & $(-0.04$ to 0.33$)$ & .13 \\
\hline \multirow{3}{*}{$\begin{array}{l}\text { Number of patients seen on regular hours } x \\
\text { week }\end{array}$} & $<40$ & ref. & & \\
\hline & $40-100$ & 0.31 & $(0.13$ to 0.48$)$ & .001 \\
\hline & $>100$ & 0.43 & $(0.24$ to 0.63$)$ & $<.001$ \\
\hline \multirow{4}{*}{ Number of weekends on call $\mathrm{x}$ month } & None & ref. & & \\
\hline & One & 0.14 & $(-0.05$ to 0.33$)$ & .15 \\
\hline & Two & 0.25 & $(0.04$ to 0.45$)$ & .02 \\
\hline & Three or more & 0.32 & $(0.10$ to 0.55$)$ & .004 \\
\hline \multirow{3}{*}{$\begin{array}{l}\text { Time dedicated to academic duties of total } \\
\text { working hours }\end{array}$} & $<10 \%$ & ref. & & \\
\hline & $10 \%-30 \%$ & -0.17 & $(-0.36$ to 0.01$)$ & .07 \\
\hline & $>30 \%$ & -0.20 & $(-0.39$ to 0.01$)$ & .05 \\
\hline \multirow{3}{*}{$\begin{array}{l}\text { Time dedicated to administrative duties of total } \\
\text { working hours }\end{array}$} & $<5 \%$ & ref. & & \\
\hline & $5 \%-10 \%$ & 0.11 & $(-0.06$ to 0.27$)$ & .21 \\
\hline & $>10 \%$ & 0.14 & $(-0.04$ to 0.32$)$ & .12 \\
\hline Levels of career satisfaction & & -0.62 & $(-0.74$ to -0.51$)$ & $<.001$ \\
\hline Constant & & 5.45 & (4.83 to 6.08$)$ & $<.001$ \\
\hline
\end{tabular}

${ }^{*}$ Model's Akaike Information Criterion (AIC) $=802.93$

${ }^{\dagger}$ Group variance, $\sigma_{\mu}^{2}=0.04$, and individuals variance, $\sigma_{\varepsilon}^{2}=0.41$

${ }^{\ddagger}$ Model's intra-class correlation coefficient (ICC) $=0.09,95 \%$ CI, 0.02 to 0.39

The final model indicated a better fit (AIC $=802.93)$ and reported that $9 \%$ of the outcome variation was explained by clustering of practice area. Residuals for the two levels of the model were assessed and found to be reasonable, ranging between 2 and -2 standard deviations from zero. According to the final model (see equations), career satisfaction of physicians was identified as a protective predictor. Distress of physicians decreased by 0.62 per unit of increase in the levels of career satisfaction $(P<.001)$. Similarly, older physicians had 0.51 less distress than those who were younger than 41 years-old $(P<.001)$. The distress of physicians who see more than 100 patients/week and between 40 and 100 patients/week increased 0.43 units and 0.31 units, respectively, versus those who see 40 or less patients/week $(P \leqslant .001)$. The impact of workload on distress can be also observed by the number of weekends and holidays on-call per month. The distress of those who are two days and three or more days on-call per month increased $0.25(P=.02)$ and $0.32(P=.004)$ units, respectively, in comparison to those who are not on-call (see Table 4).

$$
\begin{aligned}
Y_{\text {distress }}=\beta_{0}+\beta_{1} X_{\text {Age } \_g}+ & \beta_{2} X_{\text {Gender }}+\beta_{3} X_{\text {Reg_wh }}+\beta_{4} X_{\text {\#pts }}+\beta_{5} X_{\text {Complex }}+\beta_{6} X_{\text {Acad }}+\beta_{7} X_{\text {Admin }}+\beta_{8} X_{\text {Weekends }}+ \\
& \beta_{9} X_{\text {Payment }}+\beta_{10} X_{\text {Satisfaction }}+\beta_{11} X_{\text {Complex }} X_{\text {Payment }}+\mu+\varepsilon
\end{aligned}
$$

where,

$\mathrm{X}_{\text {Age } \_ \text {: }}$ : age group, reference category=less than 41 year-old

$\mathrm{X}_{\text {Gender: }}$ physician's gender, reference category $=$ female

$\mathrm{X}_{\text {reg_wh: }}$ regular working hours per week, reference category=less than 48 hours 
$\mathrm{X}_{\# \text { pts }}$ : number of patients seen on regular hours, reference category=less than 61

$\mathrm{X}_{\text {Complex: }}$ patients with complex socio-medical conditions, reference category=less than $25 \%$

$\mathrm{X}_{\text {Acad }}$ : time dedicated to academia of total working hours, reference category=less than $10 \%$

$\mathrm{X}_{\mathrm{Admin}}$ : time dedicated to administration of total working hours, reference category=less than 5\%

$\mathrm{X}_{\text {Weekends: }}$ : number of weekends on call, reference category=none

$\mathrm{X}_{\text {Payment: }}$ payment method for practicing medicine, reference category=FFS

$\mathrm{X}_{\text {Satisfaction }}$ : levels of career satisfaction of physician

$\mu$ : group error by Forward Sortation Area (FSA) of physicians' practice office

$\varepsilon$ : individual error.

Then, the final predicting equation was:

$$
\begin{aligned}
& \mathrm{Y}_{\text {distress }}=5.45+0.04 \mathrm{X}_{\text {Age_g2 }}-0.21 \mathrm{X}_{\text {Age } \_ \text {g } 3}-0.51 \mathrm{X}_{\text {Age_g4 }}-0.07 \mathrm{X}_{\text {Gender_g2 }}-0.04 \mathrm{X}_{\text {Reg_wh_g2 }}+0.14 \mathrm{X}_{\text {Reg_wh_g3 }}+ \\
& 0.31 \mathrm{X}_{\text {\#pts_g2 }}+0.43 \mathrm{X}_{\text {\#pts } \mathrm{g} 3}+0.28 \mathrm{X}_{\text {Complex_g2 }}+0.41 \mathrm{X}_{\text {Complex_g3 }}-0.17 \mathrm{X}_{\text {Acad_g2 }}-0.2 \mathrm{X}_{\text {Acad_g3 }}+0.11 \mathrm{X}_{\text {Admin_g2 }}+ \\
& 0.14 \mathrm{X}_{\text {Admin_g3 }}+0.14 \mathrm{X}_{\text {Weekends_g2 }}+0.25 \mathrm{X}_{\text {Weekends_g3 }}+0.32 \mathrm{X}_{\text {Weekends_g4 }}+0.49 \mathrm{X}_{\text {Payment_g2 }}+0.15 \mathrm{X}_{\text {Payment_g3 }}- \\
& 0.62 \mathrm{X}_{\text {Satisfaction }}-0.53 \mathrm{XComplex \_ g2X_{ \text {Payment_g2 } }}+0.22 \mathrm{XComplex \_ g2} \mathrm{X}_{\text {Payment g3 } 3}-0.36 \mathrm{X}_{\text {Complex_g3 }} \mathrm{X}_{\text {Payment_g2 }}- \\
& 0.15 \mathrm{X}_{\text {Complex_g3 }} \mathrm{X}_{\text {Payment_g3 }}
\end{aligned}
$$

Figure. Daily distress levels of physicians by interacting covariates. The figure depicts the mean and corresponding $95 \%$ CI of predicted distress levels according to payment method and percentage of patients with complex socio-medical conditions. It appears that physicians who see more than $75 \%$ of patients with complex conditions perceived lower distress levels when paid by APPs than when paid by FFS or blended schemes. In contrast, higher levels of distress were perceived among physicians paid by APPs and FFS with a mix profile of complex cases, between $25 \%$ and $75 \%$, than those paid with blended methods.

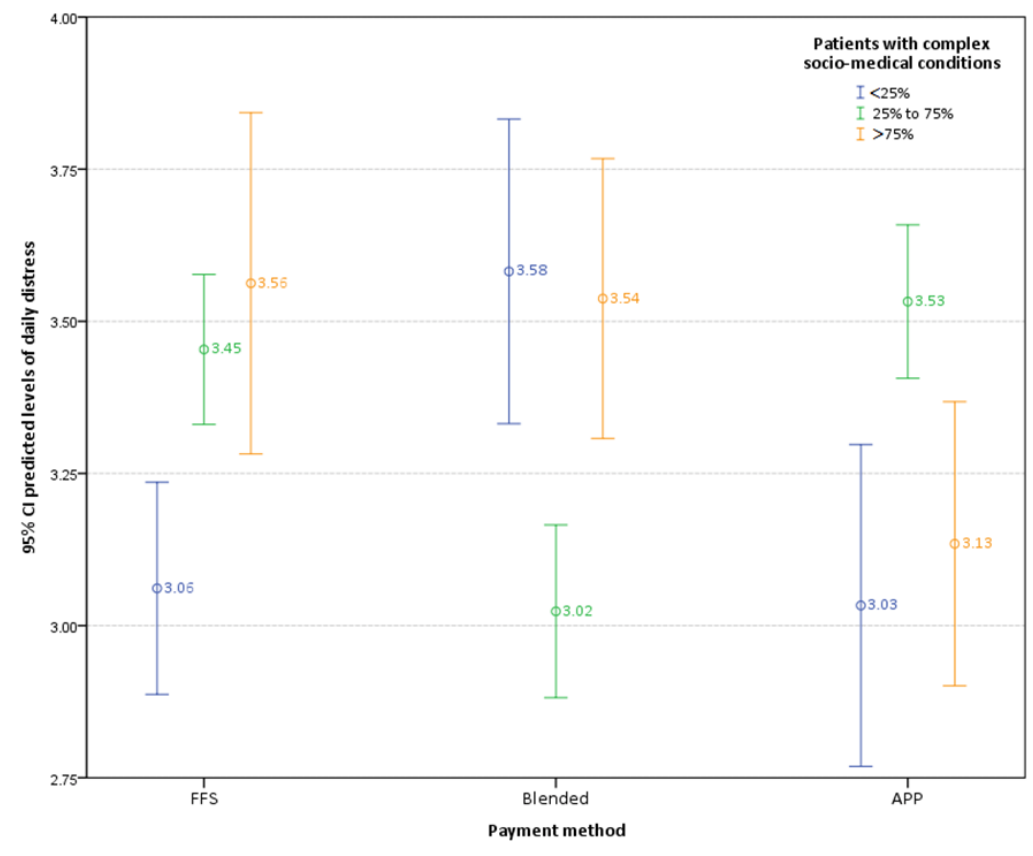

In relation to the levels of distress of physicians by payment method and percentage of patients seen with complex socio-medical conditions, the Figure presents predicted levels of distress by these interacting variables. Lower levels of distress were predicted among physicians who see more than $75 \%$ of patients with complex conditions when paid by APPs in comparison to practitioners who see the same proportion of complex cases and who are paid by FFS or blended schemes. In contrast, higher levels of distress were found among physicians with $25 \%$ to $75 \%$ of complex cases who are paid by APPs versus those paid by blended methods. Among practitioners who see a small proportion of complex cases, similar levels of distress were observed between physicians paid by APPs and FFS; conversely, there were high distress levels predicted among those paid by blended schemes. 


\section{Discussion}

Comparing distress levels of physicians according to payment method without controlling for other variables shows no differences, which is in agreement with a previous Canadian study ${ }^{[12]}$; however, this is an unadjusted evaluation which does not take into account confounders and other covariates. As our results identified in the multivariable analysis, payment method is a significant predictor of distress perceived by physicians when other predictors and confounding variables are considered in the assessment of this association. Gender ${ }^{[31,32]}$, time devoted to academic ${ }^{[9,33]}$ and administrative duties ${ }^{[9]}$, and total number of working hours ${ }^{[34]}$ are significant factors and they should be incorporated in distress models. Physicians self-select a payment method ${ }^{[35]}$ and when they are paid by non-FFS schemes they tend to distribute their time differently ${ }^{[36]}$. In our sample, physicians under APPs and mixed payment models dedicated more time to academic and administrative duties (see Table 3). Moreover, since APPs have been recommended and used to involve physicians in academic and administrative duties ${ }^{[36]}$, proportions of time dedicated to these activities are potential confounding variables which need to be considered.

Predictors of distress were identified in the mixed linear regression model. First, the fixed portion of the model demonstrated that age group, patients seen per week, weekends on call, proportion of patients with complex conditions and payment methods are relevant predictors of distress, as well as career satisfaction of physicians. The latter has been acknowledged as a protective factor ${ }^{[8,37]}$; it should be considered as an indicator of physicians' well-being, and, indirectly, of quality of care and patient safety. Second, the random component of the mixed model acknowledged those unmeasured factors at the cluster level; this was approached using the FSA, capturing a general practice environment (rural/urban location, neighborhood, hospital, clinic, medical centre, or group practice) which influences distress experienced by physicians. In fact, a previous study identified conditions in the work environment (e.g. safety programs and practice, cleanliness, orderliness, good team communication) and organizational features (e.g. teamwork, staffing ratios, quality improvement processes) as factors affecting the well-being of health professionals ${ }^{[38]}$. The psychosocial work environment matters because low job control, co-worker support, supervisor support, procedural justice, and relational justice are related with stress-related disorders ${ }^{[39]}$. Our multivariable analysis not only recognized payment method as a significant factor affecting distress of physicians but also it identified a modifier effect between payment method and the proportion of complex patients in the prediction of daily distress.

Physicians paid by APPs and who see a high proportion of complex patients probably experience less distress because they might be able to dedicate quality and quantity of time to patients with complex medical and/or social conditions. Non-FFS payment methods might be operating as an incentive to invest extra time for these patients, removing time pressure. The Nova Scotia Ministry of Health recognized that the common payment method in emergency room - FFS - frustrates and stresses physicians who perceive that FFS leads to high-volume "turnstile medicine" ${ }^{[40]}$. Physicians experience frustration because they cannot provide appropriate care to patients with complex medical conditions ${ }^{[41]}$.

Lack of time ${ }^{[41,42]}$ and inadequate payment systems ${ }^{[41]}$ have been identified as causes of inadequate care for patients with complex conditions. Innovative primary care models for patients with complex care needs require an inter-professional team, like the IMPACT Clinic initiative in Toronto ${ }^{[43,44]}$. Also, the Nova Scotia Ministry of Health strategically planned the development of APPs for emergency care physicians ${ }^{[40]}$. APPs could be a supportive choice for health care systems, providing a fixed income for comprehensive care for complex patients, putting aside time pressure. In contrast, FFS and blended schemes might not be appropriate for physicians who see high proportions of complex patients because variable components of these payment methods could add pressure to daily practice.

Since this study was cross-sectional, relationships between predictors and the distress experienced by physicians are associations. The response rate was adequate since response-bias was checked and found to be negligible. The multi-level applied technique allows controlling for environmental factors that contribute to distress of physicians on their daily practice. The results of this study could be extrapolated to physicians practicing within the SHR and other health authorities across Canada with similar characteristics to the SHR. Further studies evaluating the impact of payment methods using a longitudinal perspective are recommended. 


\section{Conclusions}

Workload, working hours, and type of patients are important covariates of distress that have to be considered in the prediction of daily distress of physicians, as well as the levels of career satisfaction of practitioners. Payment method was identified as a predictor of daily distress in the multivariable analysis, demonstrating the importance of considering other variables, such as time devoted to academic duties and time dedicated to administrative tasks, given that they could confound this relationship. Furthermore, our model identified that payment method is a predictor of daily distress which also interacts with proportion of complex cases.

APPs could be recommended to promote the provision of care for patients with complex conditions since low distress levels can be predicted among physicians who see more than three quarters of complex cases and are paid by APPs. This is a relevant finding that needs to be considered to improve well-being of practitioners engaged with provision of care for patients with complex conditions and, indirectly, ensure quality of care and outcomes among these patients.

\section{Competing interests}

The authors declare that they have no competing interests.

\section{Funding}

This study was financed by the MERCURi Group, School of Public Health, University of Saskatchewan. Doctoral studies of two authors were financed by the Western Regional Training Centre for Health Services Research (WRTC) Training Program and also from the George and Arlene Loewen Family Bursary, College of Graduate Studies and Research, University of Saskatchewan.

\section{Acknowledgement}

The authors thank the physicians who participated in the study. We express our gratitude to the Medical Affairs Office of the SHR for their support, as well as to the staff of the MERCURi Research group. We also want to thank Dr. Joe Garcea for his comments and feedback on the manuscript. Finally, we thank the School of Public Health of the University of Saskatchewan for supporting this publication.

\section{References}

[1] Shanafelt TD, Boone S, Tan L, et al. Burnout and satisfaction with work-life balance among US physicians relative to the general US population. Arch Intern Med. 2012; 172(18): 1377-85. PMid: 22911330. http://dx.doi.org/10.1001/archinternmed.2012.3199

[2] Bakker AB, Heuven E. Emotional dissonance, burnout, and in-role performance among nurses and police officers. International Journal of Stress Management. 2006; 13(4): 423-40. http://dx.doi.org/101037/1072-5245.13.4.423

[3] Myhren H, Ekeberg O, Stokland O. Job Satisfaction and burnout among intensive care unit nurses and physicians. Crit Care Res Pract. 2013. PMid: 24303211. http://dx.doi.org/10.1155/2013/786176

[4] Embriaco N, Papazian L, Kentish-Barnes N, et al. Burnout syndrome among critical care healthcare workers. Curr Opin Crit Care. 2007; 13(5): 482-8. PMid: 17762223. http://dx.doi.org/10.1097/MCC.0b013e3282efd28a

[5] Kovacs M, Kovacs E, Hegedu K. Emotion work and burnout: cross-sectional study of nurses and physicians in Hungary. Croat Med J. 2010; 51(5): 432-42. PMid: 20960593.

[6] Rutledge T, Stucky E, Dollarhide A, et al. A real-time assessment of work stress in physicians and nurses. Health Psychol. 2009; 28(2): 194-200. PMid: 19290711. http://dx.doi.org/10.1037/a0013145

[7] Renzi C, Di Pietro C, Tabolli S. Psychiatric morbidity and emotional exhaustion among hospital physicians and nurses: association with perceived job-related factors. Arch Environ Occup Health. 2012; 67(2): 117-23. PMid: 22524653. http://dx.doi.org/10.1080/19338244.2011.578682

[8] Wallace JE, Lemaire JB, Ghali WA. Physician wellness: a missing quality indicator. Lancet. 2009; 374(9702): 1714-21. PMid: 19914516. http://dx.doi.org/10.1016/S0140-6736(09)61424-0

[9] Lepnurm R, Lockhart WS, Keegan D. A measure of daily distress in practising medicine. Can J Psychiatry. 2009; 54(3): 170-80. PMid: 19321021. 
[10] Siegrist J, Shackelton R, Link C, et al. Work stress of primary care physicians in the US, UK and German health care systems. Soc Sci Med. 2010; 71(2): 298-304. PMid: 20494505. http://dx.doi.org/10.1016/j.socscimed.2010.03.043

[11] Firth-Cozens J. Doctors, their wellbeing, and their stress. BMJ. 2003; 326(7391): 670-71. PMid: 12663377. http://dx.doi.org/10.1136/bmj.326.7391.670

[12] Lee FJ, Stewart M, Brown JB. Stress, burnout, and strategies for reducing them: what's the situation among Canadian family physicians? Can Fam Physician. 2008; 54(2): 234-5. PMid: 18272641.

[13] Shanafelt TD. Enhancing meaning in work: a prescription for preventing physician burnout and promoting patient-centered care. JAMA. 2009; 302(12): 1338-40. PMid: 19773573. http://dx.doi.org/10.1001/jama.2009.1385

[14] McCue JD. The effects of stress on physicians and their medical practice. N Engl J Med. 1982; 306(8): 458-63. PMid:7057844. http://dx.doi.org/10.1056/NEJM198202253060805

[15] West CP, Tan AD, Habermann TM, et al. Association of resident fatigue and distress with perceived medical errors. JAMA. 2009; 302(12): 1294-1300. PMid:19773564 http://dx.doi.org/10.1001/jama.2009.1389

[16] Piers RD, Azoulay E, Ricou B, et al. Perceptions of appropriateness of care among European and Israeli intensive care unit nurses and physicians. JAMA. 2011; 306(24): 2694-703. PMid: 22203538. http://dx.doi.org/10.1001/jama.2011.1888

[17] Brown SD, Goske MJ, Johnson CM. Beyond substance abuse: stress, burnout, and depression as causes of physician impairment and disruptive behavior. J Am Coll Radiol. 2009; 6(7): 479-85. PMid: 19560063. http://dx.doi.org/10.1016/j.jacr.2008.11.029

[18] Lovell BL, Lee RT, Frank E. May I long experience the joy of healing: professional and personal wellbeing among physicians from a Canadian province. BMC Fam Pract. 2009; 10: 18. PMid: 19239695. http://dx.doi.org/10.1186/1471-2296-10-18

[19] Ramirez AJ, Graham J, Richards MA, et al. Mental health of hospital consultants: the effects of stress and satisfaction at work. Lancet. 1996; 347(9003): 724-8. PMid: 8602002.

[20] Canadian Institute for Health Information (CIHI). Physicians in Canada: The Status of Alternative Payment Programs, 2005-2006 [Internet]. Ottawa (ON): CIHI; 2008 [cited 2013 Sep 9]. Available from:

https://secure.cihi.ca/estore/productFamily.htm?pf=PFC1264\&lang=en\&media $=0$

[21] Canadian Institute for Health Information (CIHI). Health Care Cost Drivers: The Facts [Internet]. Ottawa (ON): CIHI; 2011 [cited 2013 Sep 9]. Available from: https://secure.cihi.ca/estore/productFamily.htm?locale=en\&pf=PFC1672

[22] Canadian Institute for Health Information (CIHI). National Physician Database, 2009-2010 Data Release [Internet]. Ottawa (ON): CIHI; 2011 [cited 2013 Sep 9]. Available from: https://secure.cihi.ca/estore/productFamily.htm?pf=PFC1678\&lang=en\&media=0

[23] Canadian Institute for Health Information (CIHI). Profiling Physicians by Payment Program: A Closer Look at Three Provinces [Internet]. Ottawa (ON): CIHI; 2010 [cited 2013 Sep 9]. Available from:

https://secure.cihi.ca/estore/productFamily.htm?pf=PFC1400

[24] Gosden T, Williams J, Petchey R, et al. Salaried contracts in UK general practice: a study of job satisfaction and stress. J Health Serv Res Policy. 2002; 7(1): 26-33. PMid: 11822258.

[25] Sutherland VJ, Cooper CL. Job stress, satisfaction, and mental health among general practitioners before and after introduction of new contract. BMJ. 1992; 304 (6841): 1545-8. PMid: 1628056.

[26] Saskatoon Health Region (SHR). Annual Report 2011-2012 Saskatoon Health Region [Internet]. Saskatoon (SK): SHR; 2012 [cited 2013 Sep 9]. Available from: http://www.saskatoonhealthregion.ca/about_us/documents/shr_annual_report_2011_12.pdf

[27] Dillman DA, Smyth JD, Christian LM. Internet, mail, and mixed-mode surveys: the tailored design method. Hoboken: Wiley \& Sons; 2009.

[28] Lepnurm R, Danielson D, Dobson R, et al. Cornerstones of career satisfaction in medicine. Can J Psychiatry. 2006; 51(8): 512-22. PMid: 16933588.

[29] DeVon HA, Block ME, Moyle-Wright P, et al. A psychometric toolbox for testing validity and reliability. J Nurs Scholarsh. 2007; 39(2): 155-64. PMid: 17535316. http://dx.doi.org/10.1111/j.1547-5069.2007.00161.x

[30] Dohoo I, Martin W, Stryhn H. Methods in Epidemiologic Research. Charlottetown: VER Inc.; 2012.

[31] Langballe EM, Innstrand ST, Aasland OG, et al. The predictive value of individual factors, work-related factors, and work-home interaction on burnout in female and male physicians: a longitudinal study. Stress and Health. 2011; 27(1): 73-87. http://dx.doi.org/10.1002/smi.1321

[32] Peña-Sánchez JN, Lepnurm R, Bermedo-Carrasco S. Latent gender inequalities in the well-being of physicians according to payment method for practicing medicine: a cross-sectional study. Journal of Hospital Administration. 2013; 2(4): p7. http://dx.doi.org/10.5430/jha.v2n4p7

[33] Shanafelt TD, West CP, Sloan JA, et al. Career fit and burnout among academic faculty. Arch Intern Med. 2009; 169(10): 990-5. PMid: 19468093. http://dx.doi.org/10.1001/archinternmed.2009.70

[34] Linzer M, Visser MR, Oort FJ, et al. Predicting and preventing physician burnout: results from the United States and the Netherlands. Am J Med. 2001; 111(2): 170-5. PMid: 11498074. 
[35] Devlin RA, Sarma S. Do physician remuneration schemes matter? The case of Canadian family physicians. J Health Econ. 2008; 27(5): 1168-81. PMid: 18586341. http://dx.doi.org/10.1016/j.jhealeco.2008.05.006

[36] Sarma S, Devlin RA, Belhadji B, et al. Does the way physicians are paid influence the way they practice? The case of Canadian family physicians' work activity. Health Policy. 2010; 98(2-3): 203-17. PMid: 20637519.

http://dx.doi.org/10.1016/j.healthpol.2010.06.019

[37] Williams E, Skinner A. Outcomes of physician job satisfaction: a narrative review, implications, and directions for future research. Health Care Manage Rev. 2003; 28(2): 119-40. PMid: 12744449.

[38] Lundstrom T, Pugliese G, Bartley J, et al. Organizational and environmental factors that affect worker health and safety and patient outcomes. Am J Infect Control. 2002; 30(2): 93-106. PMid: 11944001.

[39] Nieuwenhuijsen K, Bruinvels D, Frings-Dresen M. Psychosocial work environment and stress-related disorders, a systematic review. Occup Med (Lond). 2010; 60(4): 277-86. PMid: 20511268. http://dx.doi.org/10.1093/occmed/kqq081

[40] Ministry of Health of Nova Scotia. Better Care Sooner: the plan to improve emergency care [Internet]. Halifax(NS): Ministry of Health of Nova Scotia; 2010 [cited 2013 Sep 9]. Available from:

http://novascotia.ca/health/bettercaresooner/docs/Better-Care-Sooner-plan.pdf

[41] Ekdahl AW, Hellström I, Andersson L, et al. Too complex and time-consuming to fit in! Physicians' experiences of elderly patients and their participation in medical decision making: a grounded theory study. BMJ Open. 2012; 2(3). PMid: 22654092. http://dx.doi.org/10.10.1136/bmjopen-2012-001063

[42] Konrad TR, Link CL, Shackelton RJ, et al. It's about time: physicians' perceptions of time constraints in primary care medical practice in three national healthcare systems. Med Care. 2010; 48(2): 95-100. PMid: 20057331. http://dx.doi.org/10.1097/MLR.0b013e3181c12e6a

[43] Tracy CS, Bell SH, Nickell LA, et al. The IMPACT clinic: innovative model of interprofessional primary care for elderly patients with complex health care needs. Can Fam Physician. 2013; 59(3): e148-55. PMid: 23486816.

[44] Bell SH, Tracy CS, Upshur RE, et al. The assessment and treatment of a complex geriatric patient by an interprofessional primary care team. BMJ Case Rep 2011; 2011. PMid: 22698900. http://dx.doi.org/10.1136/bcr.07.2010.3154 